\title{
Episodic fresh surface waters in the Eocene Arctic
} Ocean

\author{
Henk Brinkhuis ${ }^{1}$, Stefan Schouten ${ }^{2}$, Margaret E. Collinson ${ }^{3}$, Appy Sluijs ${ }^{1}$, Jaap S. Sinninghe Damsté ${ }^{2,4}$, \\ Gerald R. Dickens ${ }^{5}$, Matthew Huber ${ }^{6}$, Thomas M. Cronin ${ }^{7}$, Jonaotaro Onodera ${ }^{8}$, Kozo Takahashi ${ }^{8}$, \\ Jonathan P. Bujak ${ }^{9}$, Ruediger Stein ${ }^{10}$, Johan van der Burgh ${ }^{1}$, James S. Eldrett ${ }^{11}$, lan C. Harding ${ }^{12}$, André F. Lotter ${ }^{1}$, \\ Francesca Sangiorgi ${ }^{1,2}$, Han van Konijnenburg-van Cittert ${ }^{1,13}$, Jan W. de Leeuw ${ }^{1,2}$, Jens Matthiessen ${ }^{10}$, \\ Jan Backman ${ }^{14}$, Kathryn Moran ${ }^{15} \&$ the Expedition 302 Scientists $\dagger$
}

It has been suggested, on the basis of modern hydrology and fully coupled palaeoclimate simulations, that the warm greenhouse conditions ${ }^{1}$ that characterized the early Palaeogene period (55$45 \mathrm{Myr}$ ago) probably induced an intensified hydrological cycle ${ }^{2}$ with precipitation exceeding evaporation at high latitudes ${ }^{3}$. Little field evidence, however, has been available to constrain oceanic conditions in the Arctic during this period. Here we analyse Palaeogene sediments obtained during the Arctic Coring Expedition, showing that large quantities of the free-floating fern Azolla grew and reproduced in the Arctic Ocean by the onset of the middle Eocene epoch ( $50 \mathrm{Myr}$ ago $)$. The Azolla and accompanying abundant freshwater organic and siliceous microfossils indicate an episodic freshening of Arctic surface waters during an $\sim 800,000$-year interval. The abundant remains of Azolla that characterize basal middle Eocene marine deposits of all Nordic seas ${ }^{4-7}$ probably represent transported assemblages resulting from freshwater spills from the Arctic Ocean that reached as far south as the North $\mathrm{Sea}^{8}$. The termination of the Azolla phase in the Arctic coincides with a local sea surface temperature rise from $\sim 10{ }^{\circ} \mathrm{C}$ to $13{ }^{\circ} \mathrm{C}$, pointing to simultaneous increases in salt and heat supply owing to the influx of waters from adjacent oceans. We suggest that onset and termination of the Azolla phase depended on the degree of oceanic exchange between Arctic Ocean and adjacent seas.

The recent Integrated Ocean Drilling Program (IODP) Expedition 302 (or Arctic Coring Expedition, ACEX) successfully recovered an expanded uppermost Palaeocene to middle Eocene sediment sequence from the Lomonosov ridge ${ }^{9,10}$ (Fig. 1). The sequence is barren of carbonate but comprises abundant organic matter, biosilica and pyrite 9 . Often, submillimetre laminations are present, while benthic microfossils are frequently absent ${ }^{9}$, evidencing sluggish deep water ventilation. Organic (mainly dinoflagellate cyst) and siliceous microfossil assemblages record an early Palaeogene Arctic Ocean with generally low surface water salinity. This trend culminates in a notable finding: the lowermost middle Eocene comprises microlaminated sediments with extraordinary abundances of microspore clusters (massulae) of the free-floating, freshwater fern Azolla (Figs 2 and 3, and Supplementary Fig. S-2).

Nowadays, Azolla requires standing freshwater bodies, such as ponds, canals and flooded rice fields in tropical, subtropical, and warm temperate regions. Even when the most tolerant species have experimentally been pre-conditioned by gradual increase of salt concentrations, Azolla tolerates salinities only up to $5.5 \%$, but

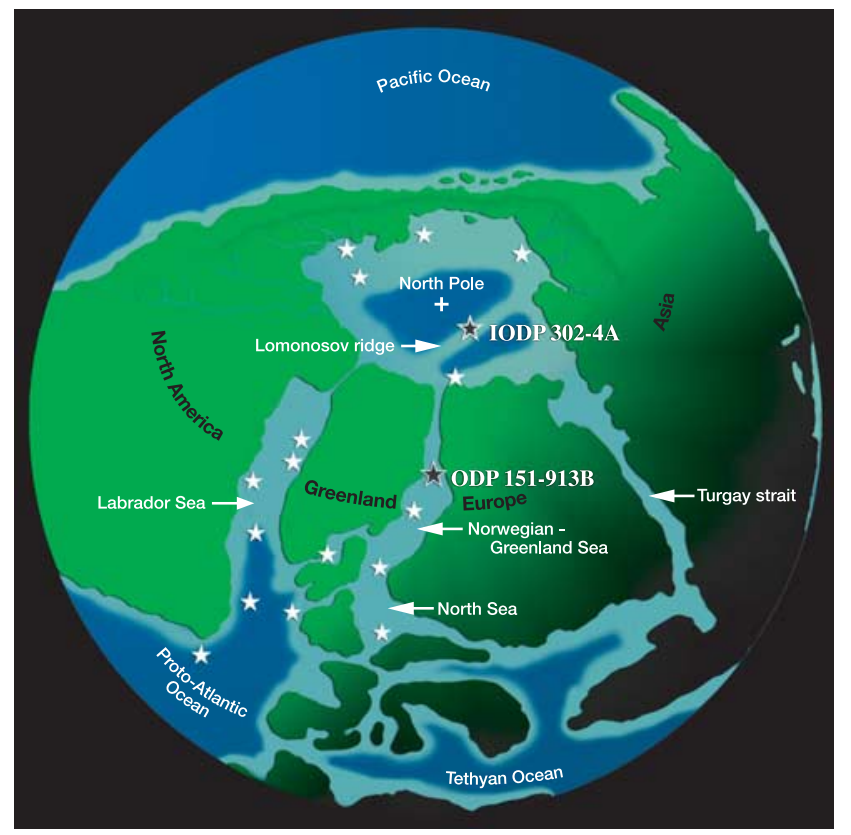

Figure 1 The early Eocene Arctic basin, site locations, and geographic distribution of the Azolla pulse in adjacent basins. Stars show pulse distribution. See Supplementary Fig. S-3 and Supplementary Table S-1 for more details.

${ }^{1}$ Palaeoecology, Institute of Environmental Biology, Utrecht University, Laboratory of Palaeobotany and Palynology, Budapestlaan 4, 3584 CD Utrecht, The Netherlands. ${ }^{2}$ Royal Netherlands Institute for Sea Research (NIOZ), Department of Marine Biogeochemistry and Toxicology, PO Box 59, 1790 AB, Den Burg, Texel, The Netherlands. ${ }^{3}$ Department of Geology, Royal Holloway University of London, Egham, Surrey, TW20 OEX, UK. ${ }^{4}$ Department of Earth Sciences, Utrecht University, Budapestlaan 4, 3584 CD Utrecht, The Netherlands. ${ }^{5}$ Department of Earth Sciences, Rice University, 6100 Main Street, Houston, Texas 77005, USA. ${ }^{6}$ Earth and Atmospheric Sciences Department and the Purdue Climate Change Research Center, Purdue University, 550 Stadium Mall Drive, West Lafayette, Indiana 47906, USA. ${ }^{7}$ USGS National Center, 12201 Sunrise Valley Drive, Reston, Virginia 20192, USA. ${ }^{8}$ Department of Earth and Planetary Sciences, Kyushu University, Fukuoka 812-8581, Japan. ${ }^{9}$ Bujak Research International, 105 North Park Drive, Blackpool, FY3 8NE, UK. ${ }^{10}$ Alfred Wegener Institute for Polar and Marine Research, Columbusstrasse, 27568 Bremerhaven, Germany. ${ }^{11}$ Shell UK Exploration and Production, 1 Altens Farm Road, Nigg, Aberdeen, AB12 3FY, UK. ${ }^{12}$ School of Ocean \& Earth Science, Southampton Oceanography Centre, University of Southampton, European Way, Southampton,

SO14 3ZH, UK. ${ }^{13}$ National Museum of Natural History, 'Naturalis', PO Box 9517, 2300 RA Leiden, The Netherlands. ${ }^{14}$ Department of Geology and Geochemistry, Stockholm University, Stockholm, SE-10691, Sweden. ${ }^{15}$ University of Rhode Island, Bay Campus, Narragansett, Rhode Island 02882, USA.

$\dagger$ A list of authors and affiliations appears at the end of the paper. 
normally Azolla cannot tolerate salinities higher than 1-1.6\% (refs 11, 12). Azolla fossils are known from the mid-late Cretaceous onwards and occupied freshwater habitats, as reconstructed from a number of widely distributed complete fertile plants of several fossil species $^{13,14}$. The Azolla-rich sediments $\left((5-30) \times 10^{4}\right.$ remains per gram dry sediment) are characterized by a total organic carbon (TOC) content of $\sim 5 \%$ (Fig. 2), compared to an early Palaeogene average of 3\% (ref. 9). Azolla maxima co-vary with physical parameters such as sediment density and magnetic susceptibility and with TOC content, suggesting that in these intervals Azolla remains constitute a dominant organic component of the bulk sediment (Fig. 2, Supplementary Fig. S-2). At Azolla maxima, megaspores with or without attached microspore massulae and separate soral clusters of microspore massulae can be picked from sieved residues occurring at comparable abundances to those documented in Palaeogene microlaminated freshwater pond facies ${ }^{15}$ (Fig. 3, Supplementary Fig. S-2). On the basis of detailed light- and electron-microscopy studies of the Azolla microspore massulae, glochidia and megaspores, a morphological similarity is suggested with Azolla areolata, a species found only in Banks Island (District of Franklin) in the Eureka Sound group, Canadian High Arctic, in sediments with a tentative Palaeocene to Eocene age ${ }^{16}$. However, several distinctive features suggest that the specimens from the Lomonosov ridge probably constitute a new species of Azolla.

The palaeoecological and palaeoclimatological implications of the Arctic Azolla phase depend on whether the remains were brought in by periodic mass transport from freshwater bodies on adjacent continents, or if Azolla grew and reproduced in situ in the Arctic Ocean. The presence of mature megaspores with and without attached massulae, single, small groups and large clusters of massulae and probable aborted megaspores of Azolla in the ACEX material (Fig. 3, Supplementary Fig. S-2) all indicate that it is highly unlikely that this reflects a transported assemblage. This is strongly supported by the relative scarcity of terrestrially derived palynomorphs (pollen and spores). Further, values of the BIT (branched and isoprenoid tetraether) index, a measure for the amount of river-derived terres- trial organic matter relative to marine organic matter ${ }^{17}$, are extremely low $(<0.1)$, in marked contrast to values characteristic of the Palaeocene/Eocene thermal maximum that are found further down hole $^{18}$. Collectively, this information reflects the distal position of the site and in situ Azolla growth. Azolla maxima in the bulk samples analysed from Cores 302-4A-11X and 302-4A-12X are accompanied by the lowest numbers and diversities of presumed exclusively marine plankton (Fig. 2) but high numbers of freshwater chrysophyte cysts (up to $1 \times 10^{7}$ per gram dry sediment; Fig. S-2). Hence, we conclude that surface waters of the central Arctic Ocean during the start of the middle Eocene were fresh enough to allow in situ growth and reproduction of Azolla.

However, brackish-marine dinocysts and notably diatoms, silicoflagellates and ebridians (up to $2 \times 10^{7}$ per gram dry sediment) continue to be present in all samples of the Azolla interval. Microscopy of the laminae indicates that the marine siliceous microfossils are concentrated in the light layers that are alternating with the dark, organic-rich Azolla layers (Supplementary Fig. S-2). Because the current age model ${ }^{9}$ allows the laminae to be possibly annual, they may reflect alternations of early spring brackish phytoplankton blooms followed by a late spring to summer precipitation increase, resulting in a stable stratified freshwater surface layer allowing rapid chrysophyte and Azolla growth. The frequency of the cyclic fluctuations in Azolla remains, density and magnetic susceptibility is about $1.3 \mathrm{~m}$ (Fig. 2). Given the average early Palaeogene accumulation rates of $\sim 1.3 \mathrm{~cm} \mathrm{kyr}^{-1}$ in Hole $4 \mathrm{~A}$ (ref. 9), these oscillations may reflect orbital forcing of the $\sim 100$-kyr eccentricity cycle, suggesting that the periodical freshening of the Arctic Ocean was astronomically modulated.

Abundant Azolla remains have previously been reported from the basal middle Eocene from all Nordic seas ${ }^{4-8}$, predominantly through unpublished commercial oil and gas exploration studies (Supplementary Information). However, so far no particular attention has been given to the recognition, cause and implications of this unique phenomenon. The basal middle Eocene Azolla pulses in the Nordic seas are consistently associated with the last (abundant)
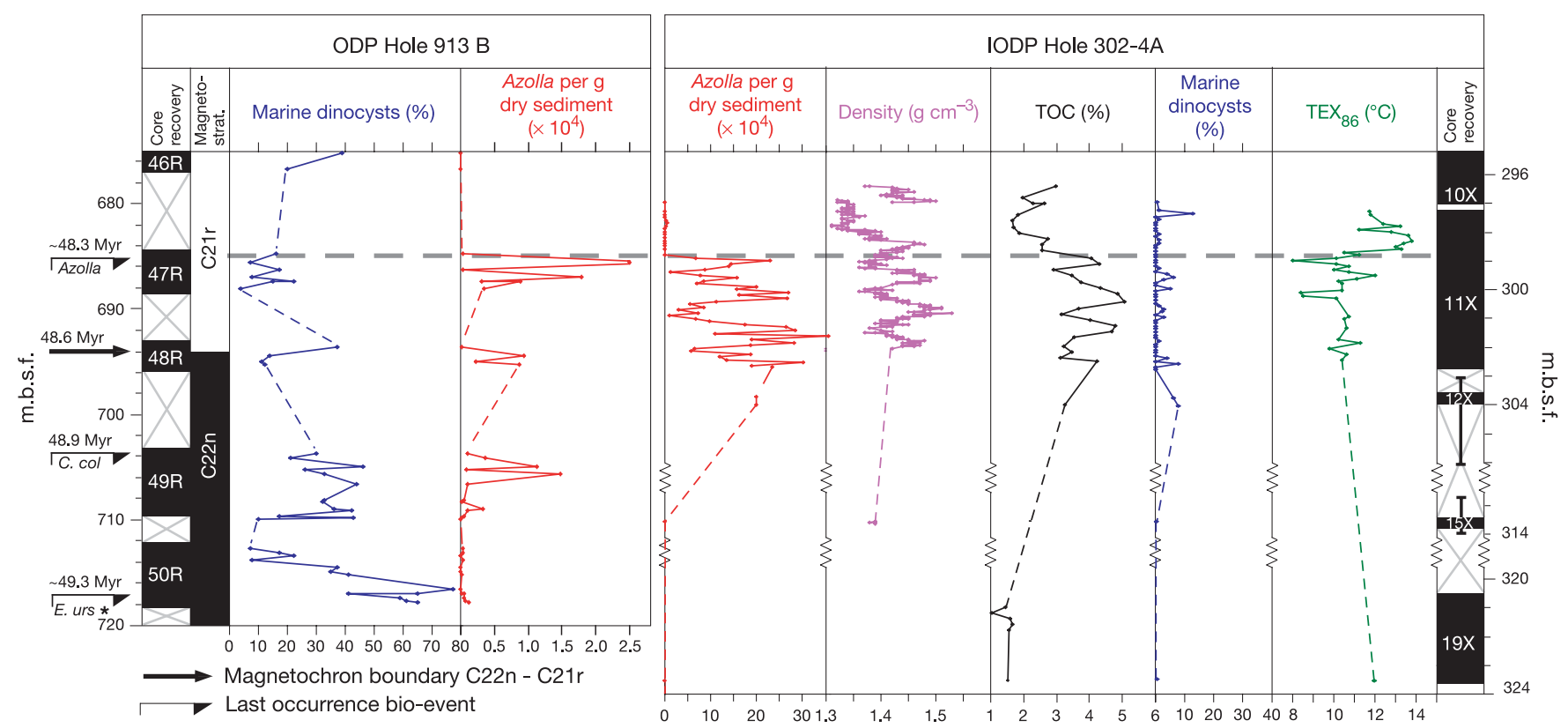

Figure 2 | Core recovery, chronology, palynological, physical properties and geochemical data across the Azolla phase of holes 302-4A and 913B.

Correlation is based on the termination of the Azolla phase, and the general ACEX age model ${ }^{9}$. E. urs. and C. col refer to the dinocysts Eatonicysta ursulae and Charlesdowniea columna, respectively, and the asterisk indicates

'abundant'. TOC, total organic carbon; m.b.s.f., metres below sea floor;
$\mathrm{TEX}_{86}$, an organic palaeothermometer. Numbers in core and recovery columns refer to core numbers. 'Magnetostrat.' indicates

magnetostratigraphy (that is, the measured direction of the palaeomagnetic field, and the number of the corresponding magnetochron recognized, Chron C22n or Chron C21r). 
occurrences of two marine dinocyst $\operatorname{species}^{6}$ (Fig. 2), indicating that they are synchronous. The top of this interval (also referred to as the 'Megaspore sp. 1 Event', ref. 7), is widely used as a stratigraphic marker in industrial boreholes and outcrops ${ }^{5,6,8}$ (Fig. 1, Supplementary Fig S-3, Supplementary Table S-1). The termination of the Azolla phase has recently been shown to occur within magnetochron C21r ( $\sim 48.3 \mathrm{Myr}$ ago $)$ at sites from the Greenland and Norwegian seas, notably in ODP Hole 913B (ref. 6; Fig. 2). The timing of its onset is less certain, but is estimated at around $49 \mathrm{Myr}$ ago $^{6}$. Although we have not yet been able to show involvement of identical Azolla species and the dinocyst markers are absent in the Arctic sediments, such an age assessment is well in line with the current age model for the Palaeogene ACEX cores, and we thus infer the pulses are time-correlative horizons across the Arctic and Nordic seas.

The number of Azolla remains per gram sediment in IODP Hole $4 \mathrm{~A}\left(\sim 25 \times 10^{4}\right)$ is ten times that in ODP Hole 913B $\left(2.5 \times 10^{4}\right)$, while average sedimentation rates $\left(\sim 1.3 \mathrm{~cm} \mathrm{kyr}^{-1}\right.$ at Hole $4 \mathrm{~A}$ and $\sim 3.0 \mathrm{~cm} \mathrm{kyr}^{-1}$ at Hole 913B; refs 6, 9) are only about 2.3 times lower in the Arctic. Hence, Azolla fluxes to the sea floor were significantly higher in the Arctic Ocean than in the adjacent seas. Also, at Hole 913B the Azolla interval is accompanied by much higher percentages of marine dinocysts than recorded on Lomonosov ridge (Fig. 2). In addition, the Azolla fluxes at Hole 913B and other Nordic sea sites (Supplementary Fig. S-3, Supplementary Table S-1) were still too

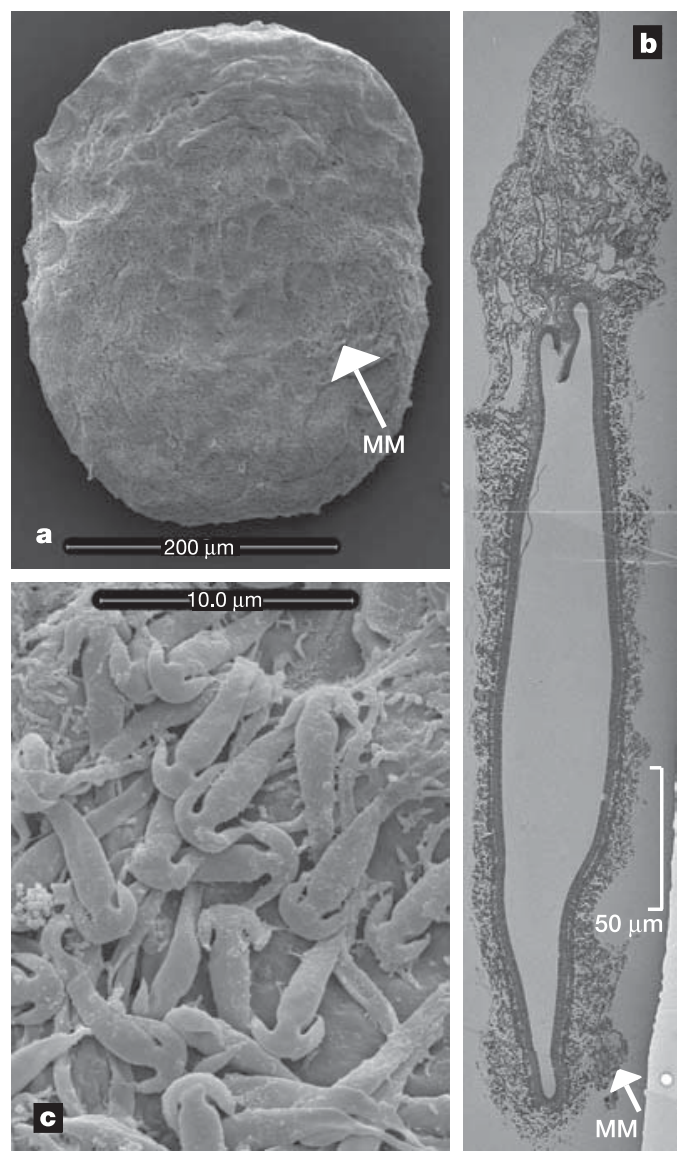

Figure 3 Azolla mega- and microspores from Hole 302-4A-11X. a, SEM image of a megaspore apparatus, showing the outer dense alveolate wall and proximal cap of sporangial tissue (uppermost part of specimen); a microspore massula (MM) is attached. $\mathbf{b}$, TEM image of a megaspore apparatus in longitudinal section, showing distal spore and proximal float zone, with fully developed spore wall and expanded spore; a microspore massula (MM) is attached. c, SEM image of fully developed glochidia on microspore massula showing anchor-shaped tips and distal dilation. See Supplementary Fig. S-2 for further documentation of Azolla. high to result from river input. These aspects support a scenario of Arctic basin Azolla mats being transported through huge Arctic freshwater plumes, to as far south as the southern North Sea basin ${ }^{8}$.

The onset as well as the demise of the Azolla phase in the Arctic Ocean potentially involved many factors that can change surface water conditions, such as temperature, salinity and mixing. We, therefore, estimated Arctic sea surface temperatures (SSTs) by applying the $\mathrm{TEX}_{86}$ index, an organic palaeothermometer that is independent of salinity ${ }^{19-21}$ and calibrated to mean annual temperature. $\mathrm{TEX}_{86}$ values suggest SSTs of $\sim 10^{\circ} \mathrm{C}$ during, and $13-14{ }^{\circ} \mathrm{C}$ immediately following, the Azolla phase (Fig. 2). These values are similar to, or slightly higher than, other late Palaeocene and Eocene floral, faunal and isotopic proxy evidence for mean annual temperature in the Arctic ${ }^{22-26}$. Among several hypotheses to explain such high-latitude warmth, the leading (and not incompatible) two are increased heat transport and increased atmospheric greenhouse gas concentrations, as well as their associated feedbacks ${ }^{27-30}$.

ACEX results for various time intervals indicate that relatively fresh conditions characterized the Arctic Ocean during the early Palaeogene $e^{9,10,18}$, matching results from climate model experiments (Supplementary Fig. S-1), but only during an interval lasting $\sim 800 \mathrm{kyr}$ was the Arctic Ocean fresh enough to yield abundant in situ Azolla growth. To explain this pattern, we propose that the $\sim 3{ }^{\circ} \mathrm{C}$ SST increase coincident with the termination of the Azolla phase represents a combined supply of heat and salt, resulting from the influx of waters from adjacent oceans. In contrast, the Azolla phase accompanied by relatively low temperatures (Fig. 2) suggests relatively limited combined supply of heat and salt. Such changes in heat and salinity are consistent in magnitude with the modern transports from the North Atlantic into the Arctic ${ }^{3}$, suggesting that these linked temperature-salinity signals reveal the turning on and off of a heat/salt transport switch. If correct, this implies that surface temperatures of $\sim 11^{\circ} \mathrm{C}\left(\sim 20^{\circ} \mathrm{C}\right.$ warmer than today) prevailed in the Eocene Arctic without ocean heat transport. This indicates that increased greenhouse gas concentrations and associated feedbacks were probably the dominant factor in keeping high latitudes warm in the early Palaeogene.

\section{METHODS}

Palynology. Sediments were oven-dried at $60^{\circ} \mathrm{C}$. To $\sim 2 \mathrm{~g}$ of sediment, a known amount of Lycopodium spores were added, after which the sample was treated with $30 \% \mathrm{HCl}$ and twice with $30 \% \mathrm{HF}$ for carbonate and silicate removal, respectively. After sieving over a $15-\mu \mathrm{m}$ nylon mesh sieve, residues were analysed at $500 \times$ magnification. Absolute quantitative numbers were calculated using the relative number of Lycopodium.

Palaeobotany. A sediment sample (302-4A-11X, 111-113 cm) was disaggregated in hot water followed by short ( $5 \mathrm{~min}$ ) treatment with $30 \% \mathrm{H}_{2} \mathrm{O}_{2}$. The sample was then sieved through $125-\mu \mathrm{m}$ mesh and Azolla megaspores and microspore massula clusters were picked from the particles retained on the sieve. Picked specimens were cleaned for 3 days in $60 \% \mathrm{HF}$, prepared for electron microscopy, and examined using an Hitachi H-7600 transmission electron microscope (TEM) and a FEI Quanta 200F field emission scanning electron microscope (SEM).

A portion of microlaminated sediment of the same level was embedded in epoxy resin and a polished thin section was prepared to standard thickness perpendicular to the laminations. The section was studied uncoated using an Hitachi S-3000N SEM in variable pressure mode at $70 \mathrm{~Pa}$ with a back scatter detector and elemental analysis was performed using an Oxford Instruments Link Isis series 300 energy dispersive X-ray (EDX) system. The same areas of the same section were also photographed using transmitted light microscopy and reflected plane polarized light microscopy.

Organic geochemistry. For the BIT and $\mathrm{TEX}_{86}$ analysis, powdered and freezedried sediments (1-3 g dry mass) were extracted with dichloromethane (DCM)/ methanol (2:1) by using the Dionex accelerated solvent extraction technique. The extracts were separated by $\mathrm{Al}_{2} \mathrm{O}_{3}$ column chromatography using hexane/ DCM (9:1) and DCM/methanol (1:1) as subsequent eluents to yield the apolar and polar fractions, respectively. The polar fractions were analysed for tetraether lipids and BIT and $\mathrm{TEX}_{86}$ (refs 17 and 19). TEX $_{86}$ values were converted to SST according to the equation: $\operatorname{TEX}_{86}=(0.015 \times \mathrm{SST})+0.29$ (ref. 19). Replicate analysis has shown that the error in $\mathrm{TEX}_{86}$ values is $\sim 0.01$ or $\sim 1{ }^{\circ} \mathrm{C}$. TOC was determined using a LECO elemental analyser. 


\section{Received 24 August 2005; accepted 23 February 2006.}

1. Zachos, J. C., Pagani, M., Sloan, L. C., Thomas, E. \& Billups, K. Trends, rhythms, and aberrations in global climate 65 Ma to present. Science 292, 686-693 (2001).

2. Barron, E. J., Hay, W. W. \& Thompson, S. The hydrologic cycle: A major variable during Earth history. Glob. Planet. Change 1, 157-174 (1989).

3. Huber, M., Sloan, L. C. \& Shellito, C. J. in Causes and Consequences of Globally Warm Climates in the Early Palaeogene (eds Wing, S. L., Gingerich, P. D., Schmitz, B. \& Thomas, E.) 25-47 (GSA Special Paper 369, Geological Society of America, Boulder, Colorado, 2003)

4. Boulter, M. C. Pollen and spore events from the marine Tertiary of North Europe. J. Micropalaeontol. 5, 75-84 (1986).

5. Bujak, J. P. \& Mudge, D. C. A high-resolution North Sea Eocene dinocyst zonation. J. Geol. Soc. Lond. 151, 449-462 (1994).

6. Eldrett, J. S., Harding, I. C., Firth, J. V. \& Roberts, A. P. Magnetostratigraphic calibration of Eocene-Oligocene dinoflagellate cyst biostratigraphy from the Norwegian-Greenland Sea. Mar. Geol. 204, 91-127 (2004)

7. Gradstein, F. M. \& Agterberg, F. in Quantitative Stratigraphic Correlation (eds Cubitt, J. M. \& Reyment, R. A.) 119-175 (Wiley \& Sons, Chichester, UK, 1982)

8. Heilmann-Clausen, C. in Early Paleogene Stage Boundaries. Abstracts and Field Trip Guides (ed. Molina, E.) 19 (University of Zaragoza, Zaragoza, Spain, 1996).

9. Backman, J., Moran, K., Mclnroy, D. B., Mayer, L. A. \& the Expedition 302 Scientists. Proc. IODP 302 doi:10.2204/iodp.proc.302.2006 (Integrated Ocean Drilling Program Management International, Inc., Edinburgh, 2006).

10. Moran, K. et al. The cenozoic palaeoenvironment of the Arctic Ocean. Nature doi:10.1038/nature04800 (this issue).

11. Rai, V. \& Rai, A. K. Growth behaviour of Azolla pinnata at various salinity levels and induction of high salt tolerance. Plant Soil 206, 79-84 (1998).

12. Arora, A. \& Singh, P. K. Comparison of biomass productivity and nitrogen fixing potential of Azolla SPP. Biomass Bioenergy 24, 175-178 (2003).

13. Collinson, M. E. The ecology of Cainozoic ferns. Rev. Palaeobot. Palynol. 119, 51-68 (2002)

14. Collinson, M. E. Cainozoic ferns and their distribution. Brittonia 53, 173-235 (2001).

15. Collinson, M. E. Palaeofloristic assemblages and palaeoecology of the Lower Oligocene Bembridge Marls, Hamstead Ledge, Isle of Wight. Bot. J. Linn. Soc. 86, 177-225 (1983)

16. Sweet, A. R. \& Hills, L. V. Early Tertiary species of Azolla subg. Azolla sect Kremastospora from western and arctic Canada. Can. J. Bot. 54, 334-351 (1976)

17. Hopmans, E. C. et al. A novel proxy for terrestrial organic matter in sediments based on branched and isoprenoid tetraether lipids. Earth Planet. Sci. Lett. 224, 107-116 (2004)

18. Sluijs, A. et al. Subtropical Arctic Ocean temperatures during the Palaeocene/ Eocene thermal maximum. Nature doi:10.1038/nature04668 (this issue).

19. Schouten, S., Hopmans, E. C., Schefuß, E. \& Sinninghe Damsté, J. S Distributional variations in marine crenarchaeotal membrane lipids: a new tool for reconstructing ancient sea water temperatures? Earth Planet. Sci. Lett. 204, 265-274 (2002).

20. Wuchter, C., Schouten, S., Coolen, M. J. L. \& Sinninghe Damsté, J. S. Temperature-dependent variation in the distribution of tetraether membrane lipids of marine Crenarchaeota: Implications for TEX 86 paleothermometry. Paleoceanography 19, doi:10.1029/2004PA001041 (2004).
21. Powers, L. A. et al. Crenarchaeotal membrane lipids in lake sediments: A new paleotemperature proxy for continental paleoclimate reconstruction? Geology 32, 613-616 (2004).

22. Greenwood, D. R. \& Wing, S. L. Eocene continental climates and latitudinal temperature gradients. Geology 23, 1044-1048 (1995).

23. Markwick, P. J. Fossil crocodilians as indicators of Late Cretaceous and Cenozoic climates: Implications for using palaeontological data in reconstructing palaeoclimate. Palaeogeogr. Palaeoclimatol. Palaeoecol. 137, 205-271 (1998).

24. Tripati, A., Zachos, J., Marincovich, L. Jr \& Bice, K. Late Paleocene Arctic coastal climate inferred from molluscan stable and radiogenic isotope ratios. Palaeogeogr. Palaeoclimatol. Palaeoecol. 170, 101-113 (2001).

25. Jahren, A. H. \& Sternberg, L. S. L. Humidity estimate for the middle Eocene Arctic rain forest. Geology 31, 463-466 (2003).

26. Fricke, H. C. \& Wing, S. L. Oxygen isotope and paleobotanical estimates of temperature and $\delta^{18} \mathrm{O}$-latitude gradients over North America during the early Eocene. Am. J. Sci. 304, 612-635 (2004).

27. Huber, M. \& Nof, D. The ocean circulation in the southern hemisphere and its climatic impacts in the Eocene. Palaeogeogr. Palaeoclimatol. Palaeoecol. 231, 9-28 (2006).

28. Sloan, L. C. \& Rea, D. K. Atmospheric carbon dioxide and early Eocene climate: A general circulation modeling sensitivity study. Palaeogeogr. Palaeoclimatol. Palaeoecol. 119, 275-292 (1996).

29. Pagani, M., Zachos, J. C., Freeman, K. H., Tipple, B. \& Bohaty, S. Marked decline in atmospheric carbon dioxide concentrations during the Paleogene. Science 309, 600-603 (2005)

30. Pearson, P. N. \& Palmer, M. R. Atmospheric carbon dioxide concentrations over the past 60 million years. Nature 406, 695-699 (2000).

Supplementary Information is linked to the online version of the paper at www.nature.com/nature.

Acknowledgements H.B. thanks the Netherlands Organization for Scientific Research (NWO) and Utrecht University for enabling participation in the ACEX expedition. A.S. thanks the Utrecht Biogeology Centre for funding. M.H. thanks the Purdue Research Foundation for funding. This research used samples and data provided by the Integrated Ocean Drilling Program (IODP). We thank L. Bik, T. Brain, S. Gibbons, P. Goggin, N. Holloway, J. van Tongeren, N. Welters and M. Woltering for technical support and L.J. Lourens, H. Nohr-Hansen, M. Pagani, C.E. Stickley, G.L. Williams and J.C. Zachos for discussions.

Author Contributions H.B., A.S., F.S. and J.S.E. carried out the palynology, S.S. and J.S.S.D. the TEX 86 and BIT analyses, M.E.C., J.v.d.B. and H.v.K.-v.C. the palaeobotany, J.O. and K.T. generated siliceous microfossil numbers, while R.S. generated the TOC data. M.H. carried out the comparison to climate models. J.B. and K.M. were co-chiefs on the ACEX. J.P.B. and H.B. compiled the unpublished industrial palynological records. All authors contributed to writing the paper.

Author Information Reprints and permissions information is available at npg.nature.com/reprintsandpermissions. The authors declare no competing financial interests. Correspondence and requests for materials should be addressed to H.B. (H.Brinkhuis@bio.uu.nl).

†Expedition 302 Scientists (those not listed above) Steve Clemens ${ }^{1}$, Frédérique Eynaud ${ }^{2}$, Jérôme Gattacceca ${ }^{3}$, Martin Jakobsson $^{4}$, Ric Jordan $^{5}$, Michael Kaminski ${ }^{6}$, John King ${ }^{7}$, Nalân Koc ${ }^{8}$, Nahysa C. Martinez ${ }^{9}$, David McInroy ${ }^{10}$, Theodore C. Moore Jr ${ }^{11}$, Matthew O’Regan ${ }^{7}$, Heiko Pälike $^{12}$, Brice Rea ${ }^{13}$, Domenico Rio ${ }^{14}$, Tatsuhiko Sakamoto ${ }^{15}$, David C. Smith ${ }^{7}$, Kristen E. K. St John ${ }^{16}$, Itsuki Suto ${ }^{17}$, Noritoshi Suzuki ${ }^{18}$, Mahito Watanabe ${ }^{19}$ \& Masanobu Yamamoto ${ }^{20}$

${ }^{1}$ Geological Sciences, Brown University, 324 Brook Street, PO Box 1846, Providence, Rhode Island 02912-1846, USA. ${ }^{2}$ Department de Géologie et Océanographie, Université Bordeaux 1, Avenue des facultés, c/o Bernei Housen, 33405 Talence Cedex, France. ${ }^{3}$ Department of Geophysics, CEREGE (CNRS)/University of Aix-Marseille 3, BP 80, 13545 Aix-en-Provence Cedex 4, France. ${ }^{4}$ Department of Geology and Geochemistry, Stockholm University, 10691 Stockholm, Sweden. ${ }^{5}$ Department of Earth and Environmental Sciences, Faculty of Science, Yamagata University, 1-4-12 Kojirakawa-machi, Yamagata 990-8560, Japan. ${ }^{6}$ Department of Earth Sciences, University College London, Gower Street, London WC1E 6BT, UK. ${ }^{7}$ Graduate School of Oceanography, University of Rhode Island, Narragansett Bay Campus, Narragansett, Rhode Island 02882, USA. ${ }^{8}$ Norwegian Polar Institute, Polar Environmental Center, N-9296 Tromsø, Norway. ${ }^{9}$ Department of Earth Sciences, Boston University, 685 Commonwealth Avenue, Boston, Massachusetts 02215, USA. ${ }^{10}$ British Geological Survey, Murchison House, West Mains Road, Edinburgh EH9 3LA, UK. ${ }^{11}$ Geological Sciences, University of Michigan, Ann Arbor, Michigan 48109-1063, USA. ${ }^{12}$ School of Ocean and Earth Science, University of Southampton, Southampton Oceanography Centre, European Way, Southampton SO14 3ZH, UK. ${ }^{13}$ Department of Geography and Environment, School of Geosciences, University of Aberdeen, Elphinstone Road, Aberdeen AB24 3 UF, UK. ${ }^{14}$ Department of Geology, Paleontology \& Geophysics, University of Padova, Via Giotto 1 I-35137 Padova, Italy. ${ }^{15}$ Institute for Research on Earth Evolution (IFREE), Japan Agency for Marine-Earth Science and Technology (JAMSTEC), Natsushima-cho 2-15, Yokosuka 237-0061, Japan. ${ }^{16}$ Department of Geology and Environmental Science, MSC 7703, James Madison University, Harrisonburg, Virginia 22807, USA. ${ }^{17}$ Institute of Life and Environmental Science, University of Tsukuba, Tennoudai 1-1-1, Tsukuba, Ibaraki 305-8572, Japan. ${ }^{18}$ Institute of Geology and Paleontology, Graduate School of Science, Tohoku University, Aramaki, Aoba, Aoba-ku, Sendai City 980-8578, Japan. ${ }^{19}$ Institute of Geoscience, National Institute of Advanced Industrial Science, and Technology (Geological Survey of Japan) AIST, Tsukuba Central 7, Higashi-1-1-1, Tsukuba, Ibaraki 305-8567, Japan. ${ }^{20}$ Graduate School of Environmental Earth Science, Hokkaido University, Kita-10, Nishi-5, Kita-ku, Sapporo 060-0810, Japan. 